\title{
UPAYA MENINGKATKAN AKTIVITAS DAN HASIL BELAJAR EKONOMI POKOK BAHASAN KERJASAMA EKONOMI INTERNASIONAL MENGGUNAKAN MODEL PEMBELAJARAN JIGSAW SISWA KELAS XII IPS 3 SMAN 3 KOTABUMI TAHUN PELAJARAN 2018-2019
}

\author{
Yenniati \\ SMA Negeri 3 Kotabumi
}

\begin{abstract}
This study aims to improve economic learning activities and outcomes using the Jigsaw learning model on international economic cooperation material for class XII IPS 3 students of SMA Negeri 3 Kotabumi in the 2018-2019 academic year. This research is a classroom action research, which was conducted to students of class XII IPS 3 of SMAN 3 kotabumi in the 2018-2019 academic year. In this study tested the use of Jigsaw learning models on international economic cooperation material to determine its effect on student learning outcomes. The study was divided into 2 cycles, namely for the material of cooperation between countries in the economic field and the multilateral economic cooperation body. Data collection techniques with cognitive tests and student attitude questionnaires obtained from each cycle, the results were analyzed whether there was an increase in each cycle. The results of this study indicate that, the use of Jigsaw learning models on international economic cooperation material can improve student learning outcomes in class XII IPS 3. Student learning outcomes have increased by 58\% from cycle I to cycle II, while student activity based on questionnaires has increased in cycle II where students, more disciplined, cooperative, polite and tolerant in learning. Thus the use of Jigsaw learning models in the material of international economic cooperation can improve the economic learning outcomes of students of class XII IPS 3 at SMAN 3 Kotabumi in the academic year 2018-2019.
\end{abstract}

Keyword: Jigsaw learning model, improve the economic learning outcomes

\section{PENDAHULUAN}

Pendidikan merupakan sarana mengembangkan daya pikir, kemampuan pribadi, serta tingkah laku yang lebih baik. Pendidikan dipandang sebagai sarana untuk meningkatkan keterampilan dan kecerdasan manusia oleh karena itu kualitas sumber daya manusia sangat tergantung dari kualitas pendidikan. Proses belajarmengajar yang dilakukan guru di sekolah saat ini kurang meningkatkan motivasi dan kreativitas siswa. Saat ini banyak guru yang menggunakan metode konvensional dalam kegiatan pembelajaran di kelas, sehingga suasana belajar kaku dan monoton sehingga sangat didominasi oleh guru.

Proses belajar-mengajar yang dilakukan oleh guru saat ini cenderung pada pencapaian target ketercapaian materi kurikulum, mengutamakan penghafalan 
konsep bukan pada pemahaman. Hal ini terlihat dari kegiatan belajar-mengajar di dalam kelas yang selalu didominasi oleh guru. Dalam penyampaian materi, guru menggunakan metode ceramah, siswa duduk, mencatat, dan mendengarkan informasi yang disampaikannya dan sangat sedikit peluang dan keinginan siswa untuk bertanya. Oleh karena itu, suasana pembelajaran menjadi tidak kondusif dan membosankan sehingga siswa menjadi pasif.

Upaya meningkatan prestasi dan hasil belajar siswa tidak terlepas dari berbagai faktor yang memengaruhinya. Guru kreatif sangat diperlukan untuk membuat kegiatan belajar-mengajar menjadi menarik dan mampu menim-bulkan motivasi siswa belajar. Atmosfir pembelajaran di kelas harus dirancang dan dibangun sedemikian rupa sehingga siswa dapat memperoleh kesempatan berinteraksi dengan yang lain dan pada akhirnya diperoleh prestasi belajar yang optimal. Salah satu cara yang dapat dilakukan adalah dengan menerapkan model pembelajaran kooperatif. Satu diantara model pembelajaran kooperatif adalah Jigsaw.

Model Pembelajaran kooperatif tipe JIGSAW merupakan sebuah model belajar yang menitikberatkan kerja sama kelompok. Siswa akan dibentuk secara kelompok kecil, terdiri atas 4 sampai 6 orang. Pembentukan kelompok dilakukan secara heterogen serta siswa bekerja sama saling ketergantungan positif dan bertanggung jawab secara mandiri. Terdapat kelompok ahli dan kelompok asal dalam model pembelajaran ini. Kelompok ahli adalah kelompok yang membahas materi yang sama, sementara kelompok asal adalah kelompok awal yang idbentuk sebelum kelompok ahli.

Materi pelajaran Ekonomi kelas XII tentang Kerjasama Ekonomi Internasional merupakan materi yang luas, saat mempelajarinya perlu pemahaman dan sumber referensi yang beragam. Rata-rata nilai Ekonomi siswa kelas XII IPS SMAN 3 Kotabumi pada tahun pelajaran 2017-2018 khususnya pokok bahasan Kerjasama Ekonomi Internasional, yaitu 69 yang masih dibawah nilai KKM bab tersebut sebesar 75. Hal inilah yang melatarbelakangi dilakukan penelitian dengan judul "Upaya Meningkatkan Aktivitas dan Hasil Belajar Ekonomi Pokok Bahasan Kerjasama Ekonomi Internasional Menggunakan Model Pembelajaran JIGSAW Siswa Kelas XII IPS 3 SMAN 3 Kotabumi Tahun Pelajaran 2018-2019 “

Dari hal-hal tersebut diidentifikasi permasalahan pada penelitian ini adalah adakah peningkatan Aktivitas dan hasil belajar Ekonomi Pokok Bahasan Kerjasama Ekonomi Internasional dengan menggunakan model pembelajaran JIGSAW siswa kelas XII IPS 3 SMAN 3 kotabumi tahun 
pelajaran 2018-2019? Tujuan penelitian ini adalah Meningkatkan aktivitas dan hasil belajar Ekonomi Pokok Bahasan Kerjasama Ekonomi Internasional dengan menggunakan model pembelajaran JIGSAW siswa kelas XII IPS 3 SMAN 3 kotabumi tahun pelajaran 2018-2019.

Belajar merupakan kegiatan berproses serta unsur yang sangat fundamental dalam setiap jenjang pendidikan. Arikunto (2009:19) mengartikan "belajar sebagai proses yang terjadi karena ada usaha untuk melakukan perubahan terhadap diri manusia dengan maksud memperoleh perubahan dalam dirinya baik berupa pengetahuan, keterampilan serta sikap", sedangkan menurut Surya (1981:32) definisi "belajar merupakan proses usaha yang dilakukan individu untuk memperoleh suatu perubahan tingkah laku yang baru secara keseluruhan, sebagai hasil pengalaman individu dalam interaksinya dengan lingkungan" dan Sardiman A.M, (2005:20) mendefinisikan "Belajar adalah perubahan dalam penampilan sebagai hasil praktek dan latihan".

Dari pendapat tersebut dapat disimpulkan bahwa belajar adalah proses perubahan tingkah laku menjadi lebih baik sebagai hasil pengalaman dari individu sendiri. Sudjana (2009:3) mendefinisikan "hasil belajar siswa hakikatnya merupakan perubahan tingkah laku sebagai hasil belajar dalam pengertian yang luas men- cakup bidang kognitif, afektif, dan psikomotorik". Dimyati dan Mudjiono (2006:3-4) juga menyebutkan bahwa "hasil belajar merupakan hasil dari interaksi tindak belajar dan tindak mengajar". Suryabrata (2006:297) menyatakan hasil belajar dapat didefinisikan sebagai "nilai merupakan perumusan terakhir yang dapat diberikan guru mengenai kemajuan/ prestasi belajar siswa selama masa tertentu". Berdasarkan pengertian hasil belajar di atas, disimpulkan bahwa hasil belajar adalah kemampuan-kemampuan yang dimiliki siswa setelah menerima pengalaman belajar. Kemampuan tersebut mencakup aspek kognitif, afektif, dan psikomotorik. Hasil belajar dilihat melalui kegiatan evaluasi yang bertujuan untuk mendapatkan data pembuktian yang akan menunjukkan tingkat kemampuan siswa dalam mencapai tujuan pembelajaran.

Menurut pendapat Hutabarat (1995: 11-12), hasil belajar dibagi menjadi empat golongan yaitu;

a) Pengetahuan yaitu dalam bentuk informasi, fakta, gagasan, keyakinan, prosedur, hukum, kaidah, standar, dan konsep.

b) Kemampuan yaitu berupa kemampuan untuk menganalisis, mereproduksi, mencipta, mengatur, merangkum, membuat generalisasi, berfikir rasional dan menyesuaikan. 
c) Kebiasaaan dan keterampilan, yaitu berupa kebiasaan perilaku dan keterampilan menggunakan semua kemampuan.

d) Sikap, berupa apresiasi, minat, pertimbangan dan selera.

Secara etimologi Jigsaw berasal dari bahasa ingris yaitu gergaji ukir dan juga ada yang menyebutnya dengan istilah Fuzzle, yaitu teka teki yang menyusun potongan gambar. Model pembelajaran kooperatif Jigsaw merupakan model pembelajaran kooperatif, dengan siswa belajar di kelompok kecil yang terdiri dari 4 hingga 6 orang secara heterogen dan bekerjasama, ketergantungan yang positif serta bertanggung jawab atas ketuntasan materi pelajaran yang dipelajari dan menyampaikan materi tersebut kepada kelompok yang lain. Suprijono (2009:89) mengungkapkan Model pembelajaran kooperatif Jigsaw merupakan pembelajaran kooperatif dimana guru membagi kelas dalam kelompok-kelompok kecil. Selain itu Yuzar dalam Isjoni (2010:78) mengatakan dalam pembelajaran kooperatif tipe Jigsaw siswa belajar dengan kelompok kecil yang terdiri 4 atau 6 orang, heterogen dan bekerja sama saling ketergantungan yang positif dan bertanggung jawab secara mandiri.

Dari pendapat di atas dapat disimpulkan bahwa model pembelajaran kooperatif tipe Jigsaw merupakan model pembelajaran dimana siswa belajar dalam kelompok kecil yang terdiri dari 4-5 orang dengan memperhatikan keheterogenan, bekerjasama positif dan setiap anggota bertanggung jawab mempelajari masalah tertentu dari materi yang ada dan menyampaikan materi tersebut kepada anggota kelompok yang lain.

Sesuai namanya, teknis penerapan tipe pembelajaran ini maju mundur seperti gergaji. Menurut Arends (1997), langkahlangkah penerapan model pembelajaran Jigsaw, yaitu:

\section{Awal Kegiatan Pembelajaran}

1. Persiapan Pembelajaran

- Melakukan Pendahuluan, guru menjabarkan isi topik secara umum, memotivasi siswa dan menjelaskan tujuan dipelajarinya topik tersebut.

- Materi pembelajaran kooperatif model Jigsaw dibagi menjadi beberapa bagian pembelajaran tergantung banyak anggota dalam kelompok serta banyaknya konsep materi pembelajaran yang ingin dicapai serta yang akan dipelajari oleh siswa.

- Membagi Siswa dalam Kelompok Asal dan Ahli, Kelompok dalam pembelajaran kooperatif model Jigsaw beranggotakan 3-5 orang yang heterogen baik dari kemampuan akademis, jenis kelamin, maupun latar belakang sosialnya 
- Menentukan Skor Awal yaitu skor rata-rata siswa secara individu pada kuis sebelumnya atau nilai akhir siswa secara individual pada semester sebelumnya.

2. Rencana Kegiatan Pembelajaran

- Setiap kelompok membaca dan mendiskusikan topik dan menetapkan anggota ahli yang akan bergabung dalam kelompok ahli.

- Anggota ahli dari masing-masing kelompok berkumpul dan mengintegrasikan semua topik yang telah dibagikan sesuai dengan banyaknya kelompok.

- Siswa ahli kembali ke kelompok masing-masing untuk menjelaskan topik yang didiskusikannya.

- Siswa mengerjakan tes individual atau kelompok yang mencakup semua topik.

- Pemberian penghargaan kelompok berupa skor individu dan skor kelompok dan menghargai prestasi kelompok.

3. Sistem Evaluasi Pembelajaran

Dalam evaluasi ada tiga cara yang dapat dilakukan:

1. Mengerjakan ujian individual yang mencakup semua topik.

2. Membuat laporan individu atau kelompok.

3. Presentasi
Materi Evaluasi

1. Pengetahuan (materi) yang dikuasai oleh siswa.

2. Proses belajar yang dilakukan oleh siswa.

\section{METODE PENELITIAN}

Subyek penelitian ini adalah peserta didik kelas XII IPS 3 SMAN 3 Kotabumi tahun pelajaran 2018-2019 dengan jumlah peserta didik 34 orang. Penelitian dilaksanakan di SMAN 3 Kotabumi kelas XII IPS 3, bulan Oktober 2018. Penelitian tindakan ini dilakukan di SMAN 3 Kotabumi, Lampung Utara. Penelitian ini merupakan sebuah penelitian tindakan kelas yang dilakukan guru berdasarkan kondisi hasil belajar siswa periode sebelumnya, kegiatan diterapkan dalam upaya meningkatkan hasil belajar Ekonomi peserta didik. Tahapan langkah penelitian disusun dalam beberapa siklus penelitian. Setiap siklus tersusun atas perencanaan, pelaksanaan, pengamatan, dan refleksi. Instrumen penelitian yang digunakan oleh peneliti sebagai berikut.

\section{Angket Kemampuan Afektif}

Angket kemampuan afektif disusun untuk mengetahui sikap peserta didik selama proses belajar berlangsung menggunakan model pembelajarn kooperatif tipe Jigsaw. 


\section{Tes Kemampuan Kognitif}

Tes dilaksanakan pada akhir kegiatan pembelajaran. Hasil tes ini digunakan untuk mengukur hasil belajar ekonomi serta tingkat ketuntasan belajar.

Dalam menganalisis data digunakan rumus sebagai berikut:

a. Data hasil angket berupa penilaian afektif. Dalam penilaian afektif yang digunakan skala dengan rentang dari 5 sampai 1. Dengan demikian, jika dari penelitian ada 5 aspek yang harus diamati maka skor maksimum adalah aspek dinilai dikalikan 5. Data hasil angket penilaian afektif dihitung dengan menggunakan rumus sebagai berikut:

\section{$N I L A I=\frac{\Sigma \text { skor penjumlahan }}{\Sigma \text { tertinggi }} \times 100 \%$}

Dengan penilaian

1) Nilai $85 \%$ - $100 \%$ sangat baik

2) Nilai $69 \%-84 \%$ baik

3) Nilai $53 \%$ - $68 \%$ cukup

4) Nilai $37 \%$ - 52\% kurang

5) Nilai kurang $36 \%$ gagal

b. Hasil belajar siswa Indikator yang digunakan untuk mengukur hasil belajar siswa:

1) Aspek kognitif Standar KKM yang telah ditentukan sekolah yaitu 75 digunakan sebagai indikator untuk aspek kognitif. Hasil belajar aspek kognitif peserta didik dihitung sebagai berikut:

$$
\text { Nilai }=\frac{\text { Sjawaban benar }}{\sum \text { soal }} \times 100 \%
$$

Rata-rata hasil belajar peserta didik dihitung sebagai berikut:

$$
\bar{X}=\frac{\Sigma X}{N}
$$

Keterangan:

$\bar{X}=$ nilai rata-rata nilai siswa

$\Sigma X=$ jumlah seluruh nilai

$\mathrm{N}=$ jumlah peserta didik yang mengikuti tes

Secara klasikal jika kompetensi minimalnya peserta didik $75 \%$ maka dapat dikatakan tuntas dalam satu pokok bahasan. Dari hasil pengamatan,ditiap siklusnya apabila masih dirasakan gagal, peneliti mencari perkiraan penyebab kekurangan sekaligus alternatif solusi untuk dirancang pada tindakan berikutnya.

\section{HASIL DAN PEMBAHASAN}

Pada penelitian terdapat dua siklus dimana setiap siklus tersusun dari tahap perencanaan, tindakan, observasi dan refleksi. Pada siklus pertama siswa masih kurang memahami peranan adanya kelompok ahli, peserta didik melakukan diskusi seadanya sehingga saat kembali ke kelompok asal informasi yang didapat dari kelompok ahli tidak maksimal. Namun pada siklus kedua kesalahan tersebut sudah mulai berkurang dan tidak terdapat hambatan yang berarti serta siswa dapat menyelesaikan tugasnya dengan baik. 
Setelah melakukan dan menyelesaikan tindakan selama dua siklus didapatkan pencapaian hasil belajar sebagai berikut.

Tabel 1

Perkembangan Ketuntasan Belajar

\begin{tabular}{|c|c|c|c|c|}
\hline \multirow{2}{*}{ Siklus } & \multicolumn{2}{|c|}{ Jumlah } & \multicolumn{2}{c|}{$\begin{array}{c}\text { Prosentase } \\
(\%)\end{array}$} \\
\cline { 2 - 5 } & $\begin{array}{c}\text { Siswa } \\
\text { tuntas }\end{array}$ & $\begin{array}{c}\text { Siswa } \\
\text { tidak } \\
\text { tuntas }\end{array}$ & $\begin{array}{c}\text { Siswa } \\
\text { tuntas }\end{array}$ & $\begin{array}{l}\text { Siswa } \\
\text { tidak } \\
\text { tuntas }\end{array}$ \\
\hline Pertama & 6 & 28 & 18 & 82 \\
\hline Kedua & 25 & 9 & 76 & 24 \\
\hline
\end{tabular}

Sumber : Data diolah dari hasil penelitian

Dari hasil penilaian tes aspek kognitif diperoleh data peningkatan kemampuan pemahaman konsep pada siswa yang berkembang dengan baik. Pada tabel 1 terlihat adanya peningkatan ketuntasan belajar dari siklus 1 sampai siklus 2, dan rata-rata ketuntasan belajar siswa juga meningkat sebesar 58\%. Hasil angket tentang sikap siswa selama pembelajaran menggunakan model pembelajaran JIGSAW, jika dikaitkan dengan ketuntasan belajarnya dapat dilihat pada tabel berikut.

Tabel 2.

Tabel perkembangan sikap dan aktivitas siswa

\begin{tabular}{|c|c|c|}
\hline $\begin{array}{c}\text { Sikap dan } \\
\text { aktivitas } \\
\text { siswa }\end{array}$ & $\begin{array}{c}\text { Siklus I } \\
\text { (rata-rata) }\end{array}$ & $\begin{array}{c}\text { Siklus II } \\
\text { (rata-rata) }\end{array}$ \\
\hline Disiplin & 3 & 3,7 \\
\hline Kerja sama & 2,85 & 3,8 \\
\hline Santun & 3,44 & 4,0 \\
\hline Toleran & 2,94 & 4,1 \\
\hline
\end{tabular}

Rata - Rata kelas Siklus $1=57,63$

Rata - rata kelas siklus II $=78,1$
Sikap siswa pada pembelajaran Ekonomi materi Kerjasama Ekonomi Internasional dengan menggunakan model pembelajaran JIGSAW sangat membantu siswa dalam memahami materi pada tiap siklus. Pada siklus I guru memberikan materi sesuai dengan rencana program pengajaran (RPP) yang telah dibuat sebelumnya. Pada tahap pendahuluan atau apersepsi guru menjelaskan konsep tentang Badan kerjasama antar negara bidang ekonomi. Selanjutnya siswa berdiskusi dalam kelompok ahli tentang materi yang diperolehnya, dan menjelaskan materi yang didapat di kelompok ahli kepada anggota kelompok asal. Setelah siswa seluruh materi terkumpul dalam kelompok guru menguji hasil diskusi dengan memberi pertanyaan pada anggota kelompok secara acak. pada akhir pembelajaran siswa diberi tes formatif untuk menegetahui hasil pembelajaran hari ini.

Dari hasil tes pada siklus I menunjukkan siswa yang tuntas belajarnya sebesar $18 \%$. Hasil tersebut belum sesuai dengan target yang diharapkan. Dari hasil angket pada siklus I terlihat bahwa pendekatan pembelajaran dengan menggunakan model pembelajaran JIGSAW mulai menunjukkan sikap disiplin (3), kerja sama $(2,85)$, santun $(3,44)$ dan toleran $(2,94)$ selama proses pembelajaran Ekonomi serta untuk rata-rata kelas sebesar 57,63 termasuk dalam kategori cukup. Pada 
awal siklus I terdapat beberapa kendala yaitu:

1. siswa masih kurang memahami peranan kelompok ahli sehingga diskusi yang dilakukan seadanya, ketika kembali ke kelompok asal informasi yang diberikan kurang maksimal.

2. Siswa yang aktif lebih mendominasi diskusi, dan cenderung mengontrol jalannya diskusi

3. Siswa yang memiliki kemampuan membaca dan berpikir rendah mengalami kesulitan untuk menjelaskan materi ketika ditunjuk sebagai tenaga ahli

Pada siklus kedua guru menjelaskan konsep Badan kerjasama ekonomi multilateral Selanjutnya siswa berdiskusi dalam kelompok ahli tentang materi yang diperolehnya, dan menjelaskan materi yang didapat di kelompok ahli kepada anggota kelompok asal, disini peran guru adalah memfasilitasi dan memotivasi para anggota kelompok ahli agar mudah untuk memahami materi yang diberikan. Setelah siswa seluruh materi terkumpul dalam kelompok, guru menguji hasil diskusi dengan memberi pertanyaan pada anggota kelompok secara acak. pada akhir pembelajaran siswa diberi tes formatif untuk menegetahui hasil pembelajaran hari ini.. Pada siklus ini tanpa dibimbing oleh guru, siswa telah memahami peranaannya dalam kelompok sehingga tidak menyianyiakan fungsi dari kelompok ahli para siswa memiliki tanggung jawab dan kerja sama yang positif dan saling ketergantungan untuk mendapatkan informasi dan memecahkan masalah yang diberikan. Adapun langkah yang diambil peneliti untuk mengatasi kendala yang terjadi di siklus I yaitu terus memotivasi siswa untuk aktif berdiskusi dan memotivasi siswa untuk berusaha banyak membaca untuk memahami materi.

Dari hasil tes pada siklus II menunjukkan siswa yang tuntas belajarnya sebesar $76 \%$. Hasil tersebut sesuai dengan target yang diharapkan. Dari hasil angket pada siklus II terlihat bahwa terjadi peningkatan sikap disiplin sebesar 3,7, kerjasama 3,8, santun 4, dan toleransi 4,1 serta rata-rata aktivitas kelas sebesar 78,1 masuk kategori baik. Pada siklus kedua kesulitan yang terjadi pada siklus pertama dapat diminimalkan, seperti diskusi yang tidak maksimal.

\section{SIMPULAN}

Berdasarkan hasil penelitian dan pembahasan pada bab IV, maka PTK dengan judul "Upaya Meningkatkan Aktivitas dan Hasil Belajar Ekonomi Pokok Bahasan Kerjasama Ekonomi Internasional dengan Menggunakan Model Pembelajaran JIGSAW Siswa Kelas XII IPS 3 SMAN 3 
Kotabumi Tahun Pelajaran 2018-2019 “ dapat diambil simpulan sebagai berikut:

1. Ada peningkatan ketuntasan belajar pada pembelajaran menggunakan model pembelajaran JIGSAW dari siklus $1(18 \%)$ sampai siklus $2(76 \%)$, dan rata-rata ketuntasan belajar siswa juga meningkat sebesar $58 \%$

2. Dari hasil angket terlihat bahwa pembelajaran dengan menggunakan model pembelajaran JIGSAW dapat meningkatkan aktivitas siswa pada sikap disiplin , kerjasama, santun dan toleran dengan rata-rata aktivitas kelas sebesar $57,63 \%$ pada siklus I dan meningkat pada siklus II sebesar $78,1 \%$ sehingga disimpulkan bahwa penggunaan model pembelajarn JIGSAW dapat meningkatkan aktivitas belajar siswa pada materi Kerjasama Ekonomi Internasional.

\section{DAFTAR RUJUKAN}

A. M, Sardiman, 2005. Interaksi dan Motivasi Belajar Mengajar, Jakarta: PT. Raja

Arikunto, Suharsimi. 2009. Evaluasi Program Pendidikan. Jakarta: Bumi Aksara

Dimyati, dkk. 2006. Belajar dan Pembelajaran. Jakarta: Rineka Cipta.

Hutabarat, E.P. 1995. Cara Belajar Sebagai Pedoman Praktis Untuk Belajar Secara Efisien dan Efektif. Jakarta: BPK Gunung Agung.

Isjoni.2012. Pembelajaran Kooperatif: Meningkatkan Kecerdasan Komunikasi antar Peserta Didik. Yogyakarta: Pustaka Pelajar.

Sudjana, Nana. 2001. Penilaian Hasil Proses Belajar Mengajar. Bandung:Tarsito

Suprijono, Agus.2010. Coperative Learning Teori dan Aplikasi PAIKEM.Yogyakarta: Pustaka Pelajar.

Surya, Moh. 1981. Dasar-dasar Proses Belajar Mengajar. Bandung : SinarBaru Algensindo.

Suryabrata, Sumadi. 2006. Psikologi Pendidikan. Jakarta : Rajawali Press. 